\title{
APPLICABILITY OF DEEP LEARNING TECHNIQUES FOR CROP PROTECTION IN PLANTAIN TREE CULTIVATION
}

\author{
M. Nandhini \\ Department of Computer Science, Pondicherry University \\ Puducherry-605014, India \\ mnandhini.csc@pondiuni.edu.in \\ M. Thangadarshini \\ Department of Computer Science and Engineering, \\ Pondicherry Engineering College (PTU), Puducherry-605014, India \\ thdarshini01@gmail.com \\ Kala K. U. \\ Department of Computer Science, Pondicherry University, Puducherry-605014 India \\ kalaunni88@gmail.com \\ S. MadhusudhanaVerma \\ Department of Operations Research \& Statistical Quality Control, \\ Rayalaseema University, Andhra Pradesh, India. \\ seeverma@rediffmail.com
}

\begin{abstract}
In India, Banana is the second most important fruit crop next to mango. Its year-round availability, affordability, varietal range, taste, nutritive and medicinal value makes it the favorite fruit among all classes of people. Cultivating healthy banana is facing significant challenges on profit margin. Decision making in Plantain tree cultivation need special attention for protecting their crops and thus making their cultivation more fruitful. The nutrients, water and sunlight are stolen by the weeds from the crops. Also, the impact of various diseases and insects on banana production are devastating. In order to protect their banana crops, multiple decision making per day have to be taken by the farmers. Crop Protection, detection and prediction techniques deal with the practices of farmers used to defend their crops against weeds, insects and diseases. Agricultural Data obtained from heterogeneous sources show the Big Data characteristics such as high volume, high velocity, and high veracity. Various Deep Learning techniques are found to be suitable for analyzing these data and attain the information regarding the existence of weeds, the severity of diseases and the infections caused by pests at its early stage. It helps to recommend the precautionary measures for all these issues. This review helps the researchers to get a comprehensive idea of the currently used DL techniques for crop protection, which will help them for finding most accurate DL technique for their crops.
\end{abstract}

Keywords: Agriculture, Big Data Analytics, Convolutional Neural Network, Crop Protection, Deep Learning,Plantain Tree Cultivation

\section{Introduction}

In Indian economy, agriculture is the mainstay. It is an inevitable sector which has provided food and income for millions of people. Thus, it supports Indian economy as well. Plantain trees are the one of the major crops which has the capability of providing huge income to the farmers. Banana is the second most important fruit crop next to mango in India. Among all classes of people, banana is the most favorite fruit, since its affordability, taste, year-round availability, nutritive and medicinal value. Export potential of banana is also high. It has also good export potential. In India, while comparing with other fruit crops, the production of banana is in the first position and its area of cultivation is in the third position. Cultivating healthy banana is facing significant challenges on profit margin. Plantain is an herbaceous perennial belonging to the family Musaceae. Plantains and the cultivated varieties are derived from ancestors who are originated from the Malaysian peninsula, New Guinea and SouthEast Asia[1]. 
Farmers are not able to enjoy the income capability from plantain tree cultivation fully because there are various threats such as diseases and pests, which reduces the banana production and leads to huge financial loss. In this situation, Crop Protection techniques are inevitable for increasing the yield of the plantain tree. Crop protection techniques deals with the practices of farmers used to defend their crops against weeds, insects, and diseases. The nutrients, water and sunlight are stolen by the weeds from the crops. Also, the impact of various diseases and insects on banana production is devastating. Early stage detection and diagnosis of plant diseases help farmers to control the severity of the disease. Indicators of these diseases and pests are diverse. In early stage itself, some crops have visible disease symptoms, and some crops shows symptoms at later stages only as there will be no option to save the crop.

To identify the diseases and pests in early stage itself, constant one-to-one care over the plants will help a lot. It also assures minimized yield loss and sustains the plant quality. Unawareness of the farmers for the identifying diseases from the symptoms on the plants necessitates the development of automated systems for providing diagnostic services.

In the forthcoming sections, challenges in plantain tree cultivation, the role of AI in plantain tree cultivation, the support of big data and deep learning techniques for plantain tree protection are surveyed from the past researches and are presented in the easily understandable format.

\section{Challenges in Plantain Tree Cultivation}

Banana crop face various diseases start from its initial stage. Most of the symptoms are expressed on leaf, stem, flowers, fruits, roots and suckers. Major plantain tree diseases, their symptoms, cause and control measures are discussed in table 1 .

Table 1. Major Plantain tree diseases, Symptoms, Cause and Control measures [2,3]

\begin{tabular}{|c|c|c|c|c|}
\hline $\begin{array}{r}\begin{array}{c}\text { Dis- } \\
\text { eases }\end{array} \\
\end{array}$ & Symptoms & Cause & Control & Image \\
\hline $\begin{array}{l}\text { Anthrac- } \\
\text { nose }\end{array}$ & $\begin{array}{l}\text { Black lesions on green fruit, } \\
\text { Brown/black spots on fruit } \\
\text { peels. }\end{array}$ & Fungus & $\begin{array}{l}\text { Recommended to Spray Bavistin } \\
(1 \%) \text { and Chlorothalonil }(0.2 \%) \text { four } \\
\text { times at } 15 \text { days break. Prompt cool- } \\
\text { ing, minimizing bruising and proper } \\
\text { sanitation of handling are also helps } \\
\text { to minimize the disease. }\end{array}$ & \\
\hline $\begin{array}{l}\text { Black } \\
\text { siga- } \\
\text { toka/Yel- } \\
\text { low siga- } \\
\text { toka }\end{array}$ & $\begin{array}{l}\text { Brown/red flecks or spots on } \\
\text { topside/underside of the } \\
\text { leaves, death of leaf surface, } \\
\text { bunch not developing spots } \\
\text { with grey center and dark/yel- } \\
\text { low border. }\end{array}$ & Fungus & $\begin{array}{l}\text { Recommend the regular applica- } \\
\text { tions of fungicides, remove leaves } \\
\text { with mature spots, rice plant spacing } \\
\text { for reduce humidity and improving } \\
\text { air circulation. }\end{array}$ & \\
\hline $\begin{array}{l}\text { Panama } \\
\text { disease }\end{array}$ & $\begin{array}{l}\text { Older leaves are yellowing, } \\
\text { leaf sheaths are splitting, } \\
\text { leaves buckling and wilting, } \\
\text { death of entire canopy. }\end{array}$ & Fungus & $\begin{array}{l}\text { Recommend the utilization of dis- } \\
\text { ease-free seed pieces, there is no ef- } \\
\text { fective treatment, once plants got in- } \\
\text { fected. }\end{array}$ & \\
\hline $\begin{array}{l}\text { Rhizome } \\
\text { rot }\end{array}$ & $\begin{array}{l}\text { Break of pseudo stem from } \\
\text { rhizome, Non germination of } \\
\text { rhizome, brown/yellow and } \\
\text { watery nature of internal tissue }\end{array}$ & Bacteria & $\begin{array}{l}\text { Recommend the selection of dis- } \\
\text { ease-free and high-quality rhizomes } \\
\text { for propagation, the regular disinfec- } \\
\text { tion of each propagation tools. Dry- } \\
\text { ing of the seed pieces before plant- } \\
\text { ing. }\end{array}$ & \\
\hline $\begin{array}{l}\text { Bunchy } \\
\text { top }\end{array}$ & $\begin{array}{l}\text { Leaf margins become chlo- } \\
\text { rotic and upturned, Dark green } \\
\text { streaks found in leaves, leaves } \\
\text { will erect and brittle, not pro- } \\
\text { ducing bunches and has a } \\
\text { 'brunchy top'. }\end{array}$ & Virus & $\begin{array}{l}\text { Plantation of less susceptible varie- } \\
\text { ties, abolish disease-ridden plants } \\
\text { for preventing the blowout of the } \\
\text { disease. }\end{array}$ & \\
\hline
\end{tabular}




\begin{tabular}{|c|c|c|c|c|}
\hline $\begin{array}{l}\text { Moko } \\
\text { disease }\end{array}$ & $\begin{array}{l}\text { Wilted, chlorotic and collaps- } \\
\text { ing older leaves, collapsing of } \\
\text { pseudo stem, entire canopy } \\
\text { spread. }\end{array}$ & $\begin{array}{l}\text { Bacte- } \\
\text { rium }\end{array}$ & $\begin{array}{l}\text { Recommend Regular monitoring is } \\
\text { necessary to find the presence of dis- } \\
\text { ease, removal of male buds, disin- } \\
\text { fection of the tools and destroy the } \\
\text { infected and neighboring plants, if } \\
\text { Moco is found to be present. }\end{array}$ & $x^{2}=$ \\
\hline $\begin{array}{l}\text { Tip } \text { over } \\
\text { or bacte- } \\
\text { rial } \text { soft } \\
\text { rot }\end{array}$ & $\begin{array}{l}\text { Known as young suckers, } \\
\text { leads to rotting and emitting of } \\
\text { foul odor, found } \\
\text { Bunchy top/curly top, Collar } \\
\text { regions are getting rotten, wa- } \\
\text { ter soaked yellow/dark brown } \\
\text { cortex areas are more in. yel- } \\
\text { lowish to reddish ooze is hap- } \\
\text { pened to see, while cutting the } \\
\text { affected plants at the collar re- } \\
\text { gion. }\end{array}$ & $\begin{array}{l}\text { Bacte- } \\
\text { rium }\end{array}$ & $\begin{array}{l}\text { High humidity and temperature are } \\
\text { ideal growing conditions for the bac- } \\
\text { teria. Bacteria survive in crop debris. } \\
\text { It gets worse in hot weather, spread } \\
\text { through contaminated water and the } \\
\text { water splash from the damaged tis- } \\
\text { sues. }\end{array}$ & \\
\hline $\begin{array}{l}\text { Banana } \\
\text { bract mo- } \\
\text { saic }\end{array}$ & $\begin{array}{l}\text { Rod shaped pinkish to reddish } \\
\text { streaks on midrib, pseudo stem } \\
\text { and peduncle, mild mosaic } \\
\text { streaks on bracts, peduncle and } \\
\text { fingers, at emergence and sep- } \\
\text { aration of leaf sheath from cen- } \\
\text { tral axis suckers exhibit unu- } \\
\text { sual reddish-brown streaks, } \\
\text { leaves are clustered at crown } \\
\text { with a traveler's palm appear- } \\
\text { ance, elongated peduncle and } \\
\text { half-filled hands. }\end{array}$ & Virus & $\begin{array}{l}\text { Recommend the control of suckers } \\
\text { in the field. The disease is spreading } \\
\text { mainly through aphid vectors such } \\
\text { as Aphis gosypii, Pentolonianigro- } \\
\text { nervosa and Rhopalosiphummaidis. }\end{array}$ & \\
\hline $\begin{array}{l}\text { Banana } \\
\text { streak }\end{array}$ & $\begin{array}{l}\text { Leaves shows yellow streak- } \\
\text { ing and progressing to a black } \\
\text { streaked appearance in older } \\
\text { leaves because of excess ne- } \\
\text { crotic. }\end{array}$ & virus & $\begin{array}{l}\text { Recommend the disinfection of the } \\
\text { planting materials because bugs } \\
\text { such as Planococcuscitri, Sacchar- } \\
\text { icoccussacchari are transmited } \\
\text { through it. }\end{array}$ & \\
\hline $\begin{array}{l}\text { Infectious } \\
\text { chlorosis }\end{array}$ & $\begin{array}{l}\text { The disease occurs in all stages } \\
\text { of banana growth. Striped ap- } \\
\text { pearance of leaves since light- } \\
\text { yellow streaks from mid rib to } \\
\text { edge of the blade are found in } \\
\text { leaf veins. }\end{array}$ & Virus & $\begin{array}{l}\text { Virus is disseminated by suckers } \\
\text { and Aphis gossypi. }\end{array}$ & \\
\hline $\begin{array}{l}\text { Cigar End } \\
\text { Tip Rot }\end{array}$ & $\begin{array}{l}\text { The rotted portion of the ba- } \\
\text { nana finger is getting dried } \\
\text { with a black necrosis and } \\
\text { spreads to fruits. }\end{array}$ & Fungus & $\begin{array}{l}\text { Recommend prompt cooling, proper } \\
\text { sanitization and the removal of the } \\
\text { pistil and perianth by hand } 8-10 \text { days } \\
\text { after bunch formation, Dithane } \mathrm{M} \text { - } \\
45(0.1 \%) \text { or Topsin } \mathrm{M}(0.1 \%) \text { spray } \\
\text { reduces the spread of the disease. }\end{array}$ & \\
\hline $\begin{array}{l}\text { Crown } \\
\text { Rot }\end{array}$ & $\begin{array}{l}\text { The crown tissues become } \\
\text { black and spreads to the pulp } \\
\text { through the pedicel, leads to } \\
\text { the separation of fingers from } \\
\text { the hand }\end{array}$ & Fungus & $\begin{array}{l}\text { Dipping the bunches or hands in } \\
\text { Thiobendazole or Benomyl and/or } \\
\text { using fungicide impregnated cellu- } \\
\text { lose pad for packing is recom- } \\
\text { mended. }\end{array}$ & \\
\hline $\begin{array}{l}\text { Stem-end } \\
\text { Rot }\end{array}$ & $\begin{array}{l}\text { The flush of the fingers be- } \\
\text { comes water-soaked and soft. }\end{array}$ & Fungus & $\begin{array}{l}\text { Recommend prompt cooling, disin- } \\
\text { fection of handling facilities and hot } \\
\text { water treatment of hands. }\end{array}$ & \\
\hline
\end{tabular}




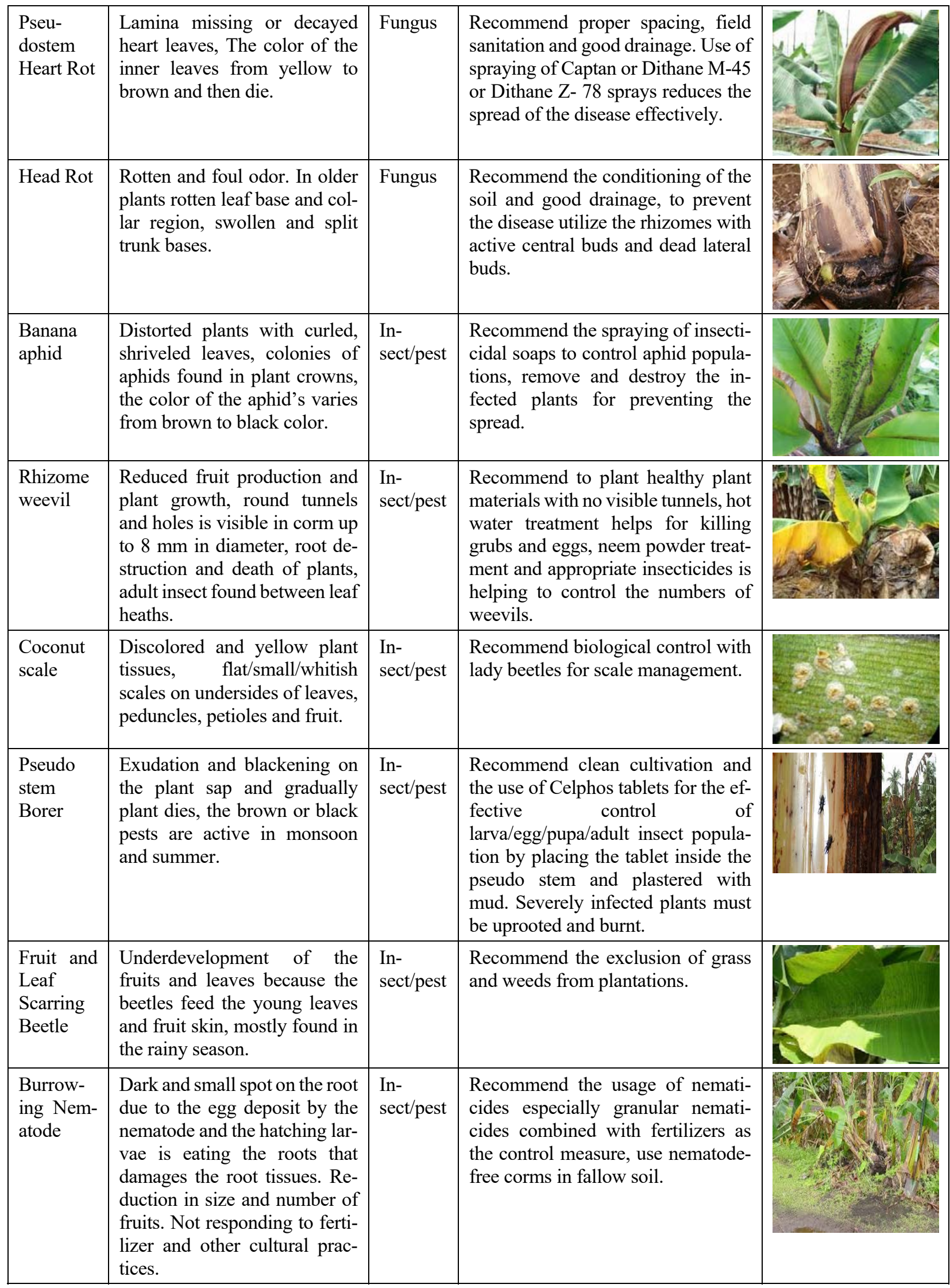




\section{Role of Artificial Intelligence in Plantain Tree Cultivation}

Usage of AI in agricultural robotics, predictive analytics, soil and crop monitoring leads to the digitization of agricultural sector. Farmers are familiar with the farm management systems for better processing and analysis of sensor, satellite, weather and soil sampling data by utilizing customized AI software. Globally the use of AI, particularly Machine Learning (ML) and Deep Learning (DL) have already proved his role in agriculture. Blue River technology, a US based company has evolved DL model for detecting weeds, their type and choosing the right herbicides for the plants. The machines can be taught about different weeds using the images from Cameras and sensors using DL techniques [4]. Then the encroachment area found, and the right herbicides are sprayed precisely. The rich set of scientific resources and the world's best research institutions of India has the capability to provide an AI software which can solve the issues faced by the farmers. The expensiveness of AI and other emerging technologies makes them unaffordable to the debt-ridden farmers and other common people.

ML and DL have transformative role in agriculture and smart farming systems [4]. Traditionally, Farmers have been managed many issues in the farming system with their own expertise and experience. This may include soil management, selection of harvesting practices, managing plant diseases, pests and weeds. Smart farming systems use advanced sensing techniques such as proximal, airborne and satellite-based image sensors along with the traditional sensors for capturing agricultural data. Well-organized storage and analytics resolutions are needed to be developed for handling the data produced through those real-time sensing and instrumentation platforms. The massive volume, velocity and variety of data produced from the sensors and real-time platforms in smart farming systems lead to a problem termed as 'Big Data'.

Once the relevant data have been captured, knowledge needed for farmers can be extracted through data analytics. The standard traditional statistical methods, such as regression, ANOVA (Analysis of Variance) and PCA (Principal Component Analysis) are used in agricultural applications conventionally. These are inadequate to deal with Big Data applications. This leads to the adoption of appropriate DL model (e.g. Convolution Neural Network $(\mathrm{CNN})$, Recurrent Neural Network (RNN)) and train them with suitable algorithm (e.g. a gradient descent method) by ensure privacy [5].

\section{Big Data and Deep Learning for Plantain Tree Protection}

Nowadays, the use of Big Data concept has become prominent in various economic and agricultural sectors. Big Data is generally denoting to complex, large, diverse, distributed or longitudinal datasets made from a variety of available sources (sensors, instruments, other digital sources or internet transactions) and in the future that are being accrued in such vast quantities which will be unbearable to manage using traditional analysis techniques [6].

Within agriculture, the bigdata can be generated from geospatial datasets, sensors, digital devices connected to the Cloud via the IOT and from already collected farm compliance data. The proper analysis of the available agricultural Big Data can provide solutions to an enormous number of thought-provoking enquiries of the farmers which could be capable of agricultural decision making with an eye to future trends [7].

Crop protection is the science and practice to manage the weeds/pests/plant diseases. Apt identification of diseases, pests and weeds in agriculture system helps farmers for controlling and managing them properly. Automatic plant disease identification and classification is also an inevitable area that necessitates the development of DL models for processing agricultural Big Data. In the past decades, different combination of image acquisition methods, image enhancement methods, image segmentation methods and feature extraction methods using DL have been attempted for disease identification and classification $[8,9]$.

This section explores the role of Big Data and various DL techniques used for the detection and prediction of Diseases/pests/weeds for the protection of crops generally.

\subsection{Big Data Analytics and Crop Protection}

The five major characteristics of Big Data are large volume, velocity, variety, veracity and valorization which are described in table 2 . The $5 \mathrm{~V}$ 's: Volume refers to size, variety refers to the multiple data sources, formats, variables and heterogeneity (unstructured/structured), velocity states the acquiring frequency (seconds to years), veracity indicates the uncertainty and inconsistency and valorization indicates the propagation of the data [10]. The first 3 characteristics (volume, velocity and valorization) of Big Data are more challenging and getting more attention nowadays [11].

The agricultural data for Crop Protection shows the characteristics of the Big Data in nature and are originated from many sources. Agricultural data can describe the processes which are carried out in the field. This include harvest, crop protection, management of weeds/pests, fertilization, planting and tilling. The data is mainly concerned with what kind of seed/fertilizer/chemicals used in the plantation and in which quantity and the manner of their application. Also, it may include chemical composition and texture of the soils, possible existence of pests and weeds in the plantation. Finally, yields are also recorded as the receipts of buyer to whom the product is sold. The most part of the data are recorded from the automatic recording machines with electronic sensors such as 
satellite digital image sensors, WSNs, soil moisture sensors, automated weather stations on farm, other sensors attached with tractors, quads, harvesters and (semi-)autonomous aerial and grund vehicles. The agricultural Big Data sources and analytic processes are shown in Fig. 1.

Table 2.Big Data Characteristics [10]

\begin{tabular}{|l|l|}
\hline Characteristics & \multicolumn{1}{|c|}{ Description } \\
\hline Volume (V1) & $\begin{array}{l}\text { The size of Big Data ranges from Terabytes to Exabytes and Zettabytes of data and they } \\
\text { are increasing exponentially every day. }\end{array}$ \\
\hline Velocity (V2) & $\begin{array}{l}\text { Big data is growing rapidly. This has to be stored, transmitted and processed rapidly to } \\
\text { meet the challenges and demands of the growth and development. }\end{array}$ \\
\hline Variety(V3) & $\begin{array}{l}\text { In Big Data, there are the variety and heterogeneity of data sources (cloud, web \& online } \\
\text { computing formats), variables, formats and heterogeneity (unstructured/unstructured). }\end{array}$ \\
\hline Veracity(V4) & $\begin{array}{l}\text { Big Data faces noise, biases and abnormality in data. Analysis accuracy is subjected to the } \\
\text { data veracity. }\end{array}$ \\
\hline Valorization(V5) & The ability to propagate knowledge, appreciation and innovation \\
\hline
\end{tabular}

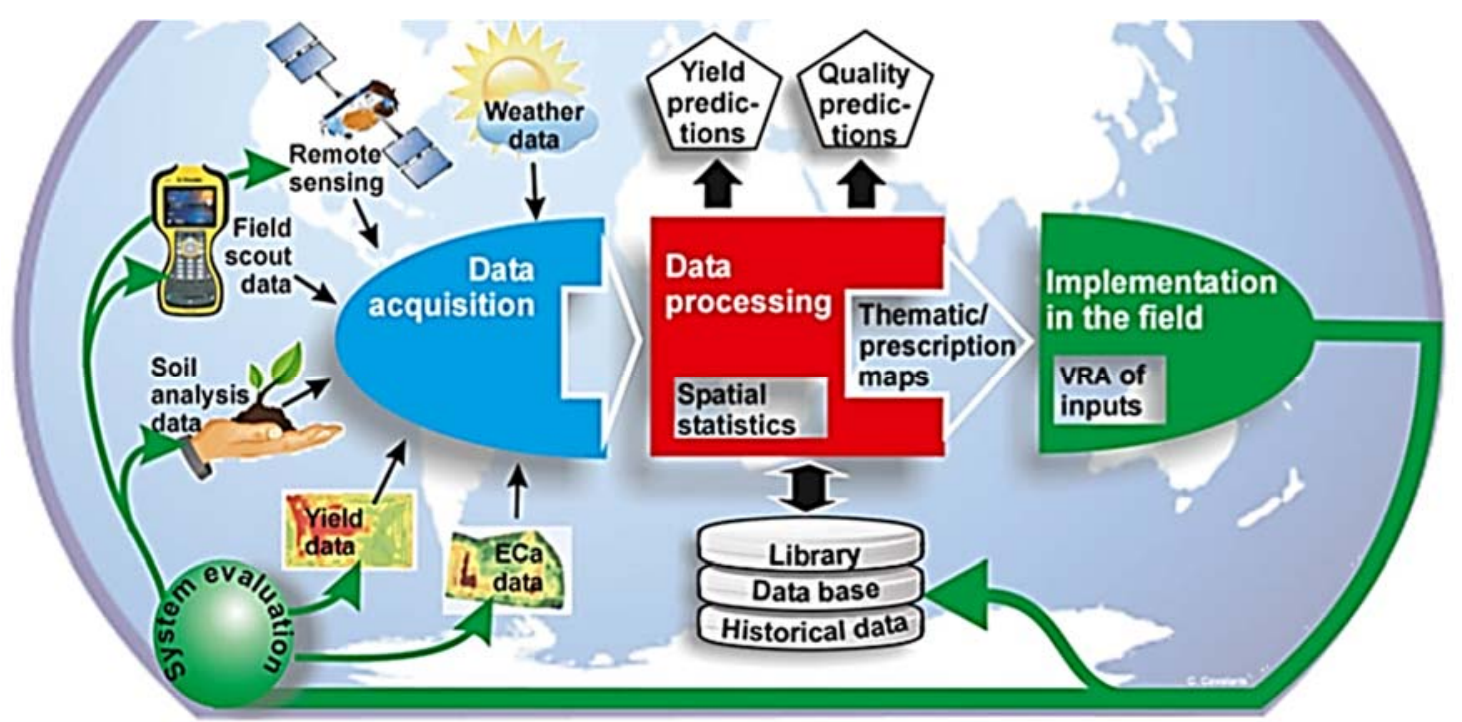

Fig.1. Sources and steps in Agriculture Big Data Analytics[11]

The process of Big Data analytics in agriculture has five major steps [11]:

(i) Data Acquisition and Storage,

(ii) Information Extraction and Cleaning,

(iii) Data Integration,

(iv) Modeling and Analysis,

(v) Interpretation and Deployment.

Big Data technologies analyze is required to deal with video, audio, image and textual data. Correspondingly, to deal with 5V's of Big Data, DL technologies are desirable to fast fitting, optimization and prediction for various decision making in the agriculture scenario. Further, a single central data base will be inadequate to store these data, so parallel storage and processing technologies are needed to be deployed. High computing power (massive storage, faster processers, fast networks, cloud computing and parallel processing), new digital sources of data and higher-level analytics (ML, DL) makes Big Data analytics suitable for generating influential understandings made about complex phenomena and thus agricultural decision making. The farmers can be interacted through the user-friendly visualization tools of Big Data analytic software's with the underlying algorithms, analyze and interpret outcomes of analysis and agricultural decision making for crop protection [4]. 


\subsection{Deep Learning techniques for Crop Protection}

Overall productivity of the nation can be increased by ensuring Crop Protection techniques. Crop protection techniques deals with the practices of farmers used to defend their crops against weeds, insects, and diseases. Multiple decisions are made each day by the farmers for protecting their crops from weeds/pests/diseases. The nutrients, water and sunlight are stolen by the weeds from the crops. Also, the impact of various diseases and insects on banana production is devastating.

Globally, AI has already proved its impressive role in agriculture. For instance, Blue River technology based on US has developed DL model which utilize sensors for detecting weeds, type of weeds and the suitable herbicides to apply on the plant. For capturing images, sensors and cameras have utilized. The machine has to learn about different weeds so that the right pesticides in the right quantity can be sprayed as per the area of encroachment. For common man, especially debt-ridden farmers, AI and other emerging technologies are out of reach since it is expensive and lack of knowledge about it. India has wide range of resources, and world's best research institutions. This can be utilized effectively and efficiently for building robust software which has the capability for providing one-time solution for all issues being faced by farmers to assist them in their effort of cultivation. Although there are various approaches exists for the identification of diseases, some recent works are mentioned here.

Lee et al. [12] presented a CNNs system for the automated recognition of plants, based on leaves images. In this paper CNN is trained for learning the feature representations of 44 diverse plant classes, chosen from the Royal Botanic Gardens, Kew, England. Grinblat et al. [13] proposed a simple and powerful NN based on the morphological patterns of leaves' veins for identifying three legume species. Mohanty et al. [14] performed a comparative study of $2 \mathrm{CNN}$ architectures for identifying 26 different diseases of plants, using an open leaf image database of 14 individual plants. The limitation of the study was that the images used are from the laboratory setups, not from the cultivation field with real conditions. Sladojevic et al. [15] proposed another most similar model to detect 13 the plant diseases among 5 plants through the images of the leaves.

Pawara et al. [16] compared CNN with other conventional pattern recognition techniques to identify the plants with three datasets of images of either entire plants and fruits or leaves of the plant and concluded that CNNs outperformed than the other conventional methods. Fuentes et al. [17] proposed a CNN model which can detect 9 diseases on tomato plants and pests on it with adequate performance. Konstantinos P. Ferentinos [18] also proposed a CNN model for identifying plant diseases. the model has been trained using the images of the leaves of diseased and healthy plants and achieved $99.53 \%$ success rate. In agricultural research, CNN consistently recognized and classified numerous biotic (fungal and bacterial diseases) and abiotic (deficiency of the nutrients and herbicide injury) stresses [19].

Azree et al. [20] proposed an application that would help rice farmers in detecting Brown PlantHopper(BPH) using deep $\mathrm{CNN}$ and image processing. It looked into specific insect pests from the imperfect sticky pad images.Three greenhouse pests such as aphid, thrips and whiteflies counted by Xia et al. [21], using Mahalanobis distance classification watershed segmentation founded on color structures. Li et al. [22] proposed a segmentation model for detecting small sized pests from the surfaces of the leaves. An agricultural robot is used to capture the images of the leaf surface. For segmenting small sizes pests (whitefly) from leaf surface region, multifractal analysis was used, and then classification based on shape and size features is performed on the segmented images.

Yalcin [23] counted moths in pheromone traps with integrated cameras under challenging illumination and environmental conditions using k-nearest neighbour algorithm. Ding and Taylor [24] proposed a 4-layer CNN model for classifying image patches to count the codling moth images taken from the field traps. Espinoza et al. [25] combined CNN with segmentation algorithm for detecting and monitoring of adult-stage thrip and whitefly in greenhouses considering color and morphological features. Ebrahimi et al. [26] proposed a combined SVM classifier and image segmentation method for detecting thrips from the images of strawberry canopy considering color and region features. Garcia et al. [27] developed a distributed grapevine moth detection system using image clustering segmentation and SVM classifier based on gray scale values and gradient in each segment.

Maharlooei et al. [28] proposed a segmentation and classification model for counting soybean aphids of different size on the leaves of a soybean considering their size for classification. Yu et al. [29] proposed a DL model running on embedded device for detecting and counting adult RTB in a pheromone trap with minimal preprocessing. The current researchers are more focused on DL-based crop protection techniques. The recent and relevant DL models focusing on various crop protection areas are summarized in Table 3.

With the emergence of AI and various digitization approaches, crop and soil protection, monitoring, their predictive analysis, and agricultural robotics, become the promising and potential areas in Indian agriculture. For better analysis and processing farmers already has been used data from farm management systems, which are gathered through various sensors and various existing soil samplings. In India agricultural regions has utilized this data along with weather information acquired from satellites has been analyzed with specific algorithms for creating customized AI software's. 
Table 3.DL based Crop Protection Models

\begin{tabular}{|c|c|c|c|}
\hline Paper ID \& year & Focused on & Purpose of the model & Techniques used \\
\hline Esgario et al. [30], 2020 & Coffee plant & Biotic stress severity estimation & CNN \\
\hline Thenmozhi et al.[31], 2019 & General & Pest classification & CNN \& Transfer Learning \\
\hline Masayukiet al.[32], 2019 & General & Aphid species pest detection & Machine Learning \\
\hline Arunnehru et al.[33], 2020 & General & Disease detection & CNN \& Transfer Learning \\
\hline Gerrit et al.[34], 2019 & Potato plant & Virus detection & CNN \\
\hline Mehmet et al.[35], 2019 & Sugar beet & Leaf spot disease detection & CNN \\
\hline Vimal et al.[36], 2019 & Rice plant & Disease detection & CNN \& Transfer Learning \\
\hline Vishal et al.[37], 2019 & General & Disease prediction & CNN \\
\hline Borja et al.[38], 2020 & General & Weed identification & CNN \& Transfer Learning \\
\hline Kun et al.[39], 2020 & General & Weed recognition & Graph based DL \\
\hline Artzai et al. [40], 2019 & General & Disease detection & CNN \\
\hline Sophia et al. [41], 2020 & Plantain tree & Disease detection & CNN \\
\hline Jialin et al. [42], 2019 & Turfgrass & Weed detection & CNN \\
\hline Mosin et al. [43], 2019 & Tomato plant & Disease detection & CNN \\
\hline Hammad et al.[44], 2020 & Rice plant & Early disease detection & Region based CNN \\
\hline Julian et al. [45], 2019 & General & Weed detection & Region based CNN \\
\hline Hamsa et al. [46], 2019 & Canola & Weed detection & CNN \\
\hline
\end{tabular}

\section{Conclusion}

Overall productivity of the nation can be increased by ensuring proper Crop Protection techniques in plantain tree cultivation. To learn and to perform in depth analysis of the behavioral changes in the sequence of images collected from vast area for a specific period of time, the DL techniques are found suitable. Build, train, and deploy fast, flexible DL model to large scale production will assist the Indian farmers for managing the cultivation of plantain tree by forecasting diseases, weeds and pests and can increase the yields.

\section{Acknowledgement}

This project work is funded by the Department of Science \& Technology - Science and Engineering Research Board, Government of India under Core Research Grant, via sanction order number CRG/2019/005513.

\section{References}

[1] "Plantain | Diseases and Pests, Description, Uses, Propagation.” [Online]. Available: https://plantvillage.psu.edu/topics/plantain/infos. [Accessed: 16-Oct-2020].

[2] G. Blomme, S. Eden-Green, M. Mustaffa, B. Nwauzoma, and R. Thangavelu, "Major Diseases of Banana," in Banana Breeding, CRC Press, 2011, pp. 85-119.

[3] "Important diseases, insects and pests of Banana and their management-Krishisewa." [Online]. Available: https://www.krishisewa.com/articles/disease-management/286-dbanana.html. [Accessed: 16-Oct-2020].

[4] R. H. L. Ip, L. M. Ang, K. P. Seng, J. C. Broster, and J. E. Pratley, "Big data and machine learning for crop protection," Comput. Electron. Agric., vol. 151, pp. 376-383, Aug. 2018, doi: 10.1016/j.compag.2018.06.008.

[5] X. Yang and M. Sun, "A Survey on Deep Learning in Crop Planting," in IOP Conference Series: Materials Science and Engineering, 2019, vol. 490, no. 6, p. 062053, doi: 10.1088/1757-899X/490/6/062053.

[6] F. K. Van Evert, S. Fountas, D. Jakovetic, V. Crnojevic, I. Travlos, and C. Kempenaar, "Big Data for weed control and crop protection," Weed Research, vol. 57, no. 4. Blackwell Publishing Ltd, pp. 218-233, 01-Aug-2017, doi: 10.1111/wre.12255.

[7] S. Wolfert, L. Ge, C. Verdouw, and M. J. Bogaardt, "Big Data in Smart Farming - A review," Agricultural Systems, vol. 153. Elsevier Ltd, pp. 69-80, 01-May-2017, doi: 10.1016/j.agsy.2017.01.023.

[8] M. Kumar and M. Nagar, "Big data analytics in agriculture and distribution channel," in Proceedings of the International Conference on Computing Methodologies and Communication, ICCMC 2017, 2018, vol. 2018-January, pp. 384-387, doi: 10.1109/ICCMC.2017.8282714.

[9] M. R. Bendre, R. C. Thool, and V. R. Thool, "Big data in precision agriculture: Weather forecasting for future farming," in Proceedings on 2015 1st International Conference on Next Generation Computing Technologies, NGCT 2015, 2016, pp. 744-750, doi: 10.1109/NGCT.2015.7375220.

[10] RaghavendraKune, Pramod Kumar Konugurthi, ArunAgarwal, RaghavendraRaoChillarige, and RajkumarBuyya. 2016. The anatomy of big data computing. Softw. Pract. Exper. 46, 1 (January 2016), 79-105. DOI=http://dx.doi.org/10.1002/spe.2374

[11] A. Kamilaris, A. Kartakoullis, and F. X. Prenafeta-Boldú, "A review on the practice of big data analysis in agriculture," Computers and Electronics in Agriculture, vol. 143. Elsevier B.V., pp. 23-37, 01-Dec-2017, doi: 10.1016/j.compag.2017.09.037.

[12] S. H. Lee, C. S. Chan, P. Wilkin and P. Remagnino, "Deep-plant: Plant identification with convolutional neural networks," 2015 IEEE International Conference on Image Processing (ICIP), Quebec City, QC, 2015, pp. 452-456. doi: 10.1109/ICIP.2015.7350839 
[13] Grinblat, G.L., Uzal, L.C., Larese, M.G., Granitto, P.M., 2016. Deep learning for plant identification using vein morphological patterns. Comput. Electron. Agric. 127, 418-424. https://doi.org/10.1016/j.compag.2018.01.009

[14] Mohanty, S.P., Hughes, D.P., Salathé, M., 2016. Using deep learning for image-based plant disease detection. Front. Plant Sci. 7http://dx.doi.org/10.3389/fpls.2016. 01419. Article: 1419.

[15] Sladojevic, S., Arsenovic, M., Anderla, A., Culibrk, D., Stefanovic, D., 2016. Deep neural networks based recognition of plant diseases by leaf image classification. Computat. Intelligence Neurosci. http://dx.doi.org/10.1155/2016/3289801. Article ID: 3289801.

[16] Pawara, P., Okafor, E., Surinta, O., Schomaker, L., Wiering, M. 2017. Comparing local descriptors and bags of visual words to deep convolutional neural networks for plant recognition. 6th Intl Conf. on Pattern Recognition Applications and Methods (ICPRAM 2017)

[17] Fuentes, A., Yoon, S., Kim, S.C., Park, D.S., 2017. A robust deep-learning-based detector for real-time tomato plant diseases and pest recognition. Sensors 17, 2022. http://dx. doi.org/10.3390/s17092022.

[18] Konstantinos P. Ferentinos, Deep learning models for plant disease detection and diagnosis Computers and Electronics in Agriculture, vol.145, pp. 311-318, 2018, DOI https://doi.org/10.1016/j.compag.2018.01.009

[19] SambuddhaGhosal, David Blystone, Asheesh K. Singh, BaskarGanapathysubramanian, Arti Singh, and SoumikSarkar, An explainable deep machine vision framework for plant stress phenotyping,PNASMay 1, 2018115 (18) 4613-4618;https://doi.org/10.1073/pnas.1716999115

[20] A. Nazri, N. Mazlan, and F. Muharam, "Research article Penyek: Automated brown planthopper detection from imperfect sticky pad images using deep convolutional neural network," PLoS One, vol. 13, no. 12, Dec. 2018, doi: 10.1371/journal.pone.0208501.

[21] Xia C, Chon TS, Ren Z, Lee JM. Automatic identification and counting of small size pests in greenhouse conditions with low computational cost. Ecological Informatics. 2015;29(9): 139-146

[22] Li Y, Xia C, Lee J. Detection of small-sized insect pest in greenhouses based on multifractal analysis. Optik-International Journal for Light and Electron Optics. 2015;126(19):2138-2143

[23] H. Yalcin, "Vision based automatic inspection of insects in pheromone traps," in IEEE Int. Conf. on Agro-Geoinformatics, 2015.

[24] Weiguang Ding and Graham Taylor. 2016. Automatic moth detection from trap images for pest management. Comput. Electron. Agric. 123, C (April 2016), 17-28. DOI: https://doi.org/10.1016/j.compag.2016.02.003

[25] Karlos Espinoza, Diego L. Valera, José A. Torres, Alejandro López, and Francisco D. Molina-Aiz. 2016. Combination of image processing and artificial neural networks as a novel approach for the identification of Bemisiatabaci and Frankliniella occidentalis on sticky traps in greenhouse agriculture. Comput. Electron. Agric. 127, C (September 2016), 495-505. DOI: https://doi.org/10.1016/j.compag.2016.07.008

[26] Ebrahimi MA, Khoshtaghaza MH, Minaei S, Jamshidi B. Vision-based pest detection based on SVM classification method. Computers and Electronics in Agriculture. 2017; 137:52-58

[27] José García, Christopher Pope, and Francisco Altimiras, "A Distributed -Means Segmentation Algorithm Applied to Lobesiabotrana Recognition,” Complexity, vol. 2017, Article ID 5137317, 14 pages, 2017. https://doi.org/10.1155/2017/5137317.

[28] Maharlooei, M.; Sivarajan, S.; Bajwa, S.G.; Harmon, J.P.; Nowatzki, J. Detection of soybean aphids in a greenhouse using an image processing technique. Comput. Electron. Agric. 2017, 132, 63-70.

[29] Yu Sun, Xuanxin Liu, Mingshuai Yuan, LiliRen, Jianxin Wang, Zhibo Chen, "Automatic in-trap pest detection using deep learning for pheromone-based Dendroctonusvalens monitoring", Biosystems Engineering, Volume 176, Pages 140-150, DOI:10.1016/j.biosystemseng.2018.10.012, December 2018.

[30] J. G. M. Esgario, R. A. Krohling, and J. A. Ventura, "Deep learning for classification and severity estimation of coffee leaf biotic stress," Comput. Electron. Agric., vol. 169, p. 105162, Feb. 2020, doi: 10.1016/j.compag.2019.105162.

[31] K. Thenmozhi and U. Srinivasulu Reddy, "Crop pest classification based on deep convolutional neural network and transfer learning," Comput. Electron. Agric., vol. 164, p. 104906, Sep. 2019, doi: 10.1016/j.compag.2019.104906.

[32] M. Hayashi, K. Tamai, Y. Owashi, and K. Miura, "Automated machine learning for identification of pest aphid species (Hemiptera: Aphididae),” Appl. Entomol. Zool., vol. 54, no. 4, pp. 487-490, Nov. 2019, doi: 10.1007/s13355-019-00642-0.

[33] J. Arunnehru, B. S. Vidhyasagar, and H. Anwar Basha, "Plant Leaf Diseases Recognition Using Convolutional Neural Network and Transfer Learning," in Lecture Notes in Electrical Engineering, 2020, vol. 637, pp. 221-229, doi: 10.1007/978-981-15-2612-1_21.

[34] G. Polder, P. M. Blok, H. A. C. de Villiers, J. M. van der Wolf, and J. Kamp, "Potato Virus Y Detection in Seed Potatoes Using Deep Learning on Hyperspectral Images," Front. Plant Sci., vol. 10, p. 209, Mar. 2019, doi: 10.3389/fpls.2019.00209.

[35] M. M. Ozguven and K. Adem, "Automatic detection and classification of leaf spot disease in sugar beet using deep learning algorithms," Phys. A Stat. Mech. its Appl., vol. 535, p. 122537, Dec. 2019, doi: 10.1016/j.physa.2019.122537.

[36] V. K. Shrivastava, M. K. Pradhan, S. Minz, and M. P. Thakur, "Rice Plant Disease Classification Using Transfer Learning Of Deep Convolution Neural Network," 2019, doi: 10.5194/isprs-archives-XLII-3-W6-631-2019.

[37] V. Pallagani, V. Khandelwal, B. Chandra, V. Udutalapally, D. Das, and S. P. Mohanty, "DCrop: A deep-learning based framework for accurate prediction of diseases of crops in smart agriculture," in Proceedings - 2019 IEEE International Symposium on Smart Electronic Systems, iSES 2019, 2019, pp. 29-33, doi: 10.1109/iSES47678.2019.00020.

[38] B. Espejo-Garcia, N. Mylonas, L. Athanasakos, S. Fountas, and I. Vasilakoglou, "Towards weeds identification assistance through transfer learning," Comput. Electron. Agric., vol. 171, p. 105306, Apr. 2020, doi: 10.1016/j.compag.2020.105306.

[39] K. Hu, G. Coleman, S. Zeng, Z. Wang, and M. Walsh, "Graph weeds net: A graph-based deep learning method for weed recognition," Comput. Electron. Agric., vol. 174, p. 105520, Jul. 2020, doi: 10.1016/j.compag.2020.105520.

[40] A. Picon, M. Seitz, A. Alvarez-Gila, P. Mohnke, A. Ortiz-Barredo, and J. Echazarra, "Crop conditional Convolutional Neural Networks for massive multi-crop plant disease classification over cell phone acquired images taken on real field conditions," Comput. Electron. Agric., vol. 167, p. 105093, Dec. 2019, doi: 10.1016/j.compag.2019.105093.

[41] S. Sanga, V. Mero, D. Machuve, and D. Mwanganda, "Mobile-Based Deep Learning Models for Banana Diseases Detection," Apr. 2020.

[42] J. Yu, S. M. Sharpe, A. W. Schumann, and N. S. Boyd, "Deep learning for image-based weed detection in turfgrass," Eur. J. Agron., vol. 104, pp. 78-84, Mar. 2019, doi: 10.1016/j.eja.2019.01.004.

[43] M. Hasan, B. Tanawala, and K. J. Patel, "Deep Learning Precision Farming: Tomato Leaf Disease Detection by Transfer Learning," SSRN Electron. J., Apr. 2019, doi: 10.2139/ssrn.3349597.

[44] M. H. Masood, H. Saim, M. Taj, and M. M. Awais, "Early Disease Diagnosis for Rice Crop,” Apr. 2020.

[45] J. Champ, A. Mora-Fallas, H. Goëau, E. Mata-Montero, P. Bonnet, and A. Joly, "Instance segmentation for the fine detection of crop and weed plants by precision agricultural robots," Appl. Plant Sci., vol. 8, no. 7, Jul. 2020, doi: 10.1002/aps3.11373.

[46] M. H. Asad and A. Bais, "Weed detection in canola fields using maximum likelihood classification and deep convolutional neural network,” Inf. Process. Agric., Dec. 2019, doi: 10.1016/j.inpa.2019.12.002. 